\title{
التحولات الحاصلة في أشكال ومضامين التعليم الإسلامي في تركيا المعاصرة \\ خطوات هامة نحو تفعيل عناصر التعليم الإسلامي
}

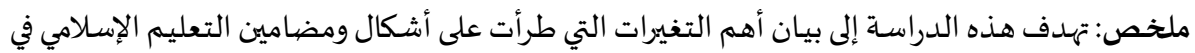

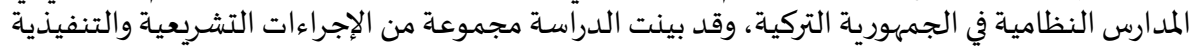

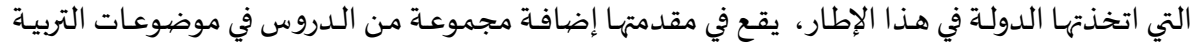

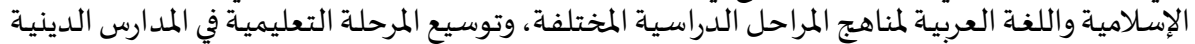

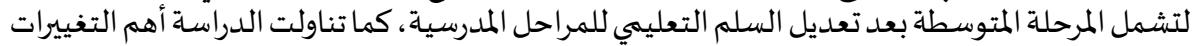

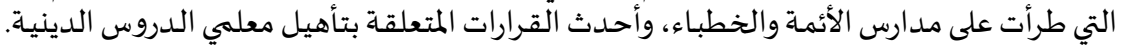
الكلمات المفتاحية: السياسـة الداخلية، الجمهورية التركية، التعليم الديني.

\section{Abstract: The Changes That Taking Place in The Forms and Contents of Islamic Education in Contemporary Turkey: an Important Steps Towards Activating Elements of Islamic Education:}

This study aims to explane The Changes That Taking Place in The Forms and Contents of Islamic Education in formal schools in the Republic of Turkey, The study showed important changes that have occurred through adding a range of lessons in subjects of Islamic education and Arabic language, and through expansion the educational stage in religious schools to include the intermediate stage after amening the educational system. The study also dealt with the most important changes that have occurred in imams and preachers schools, and the latest decisions concerning the rehabilitation of religious lessons teachers.

Keywords: Internal politics, Turkey, religious education

* $\quad$ Doç. Dr., Yermouk Üniversitesi İlahiyat Fakültesi Öğretim Üyesi. 
لقـد أثرت عوامل متعـددة ومتداخلـة في صناعـة السياسـة التعليميـة الداخليـة المتعلقـة بالتعليم الديني أو التعليم الإسـلامي

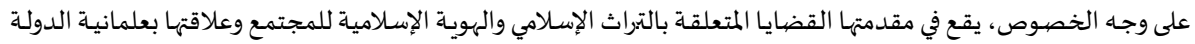

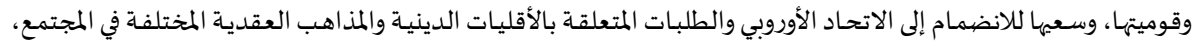

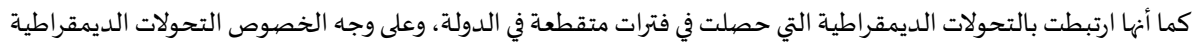

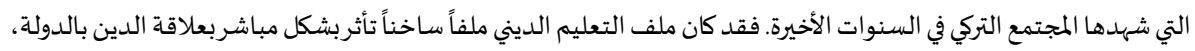

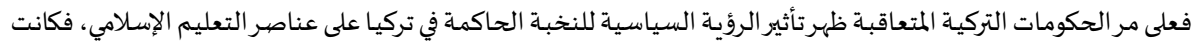

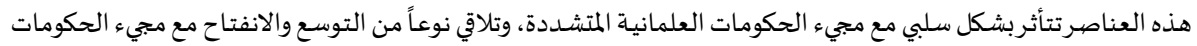

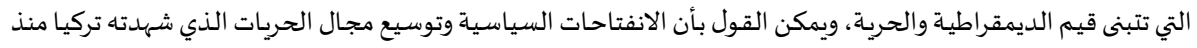

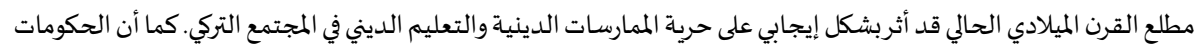

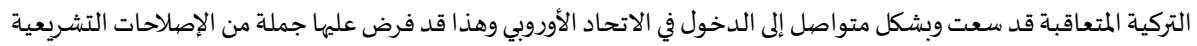

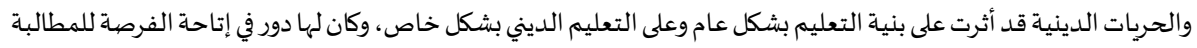

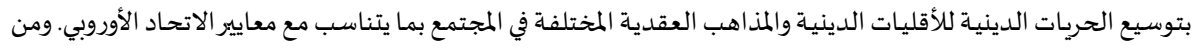

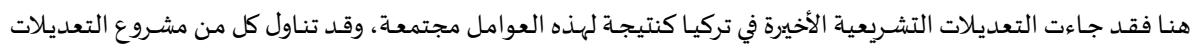

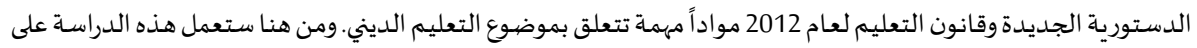
بيان هذه التحولات ومناقشتها وأثرها على عناصر التعليم الديني الرسمي في هذه الدوان الدولة.

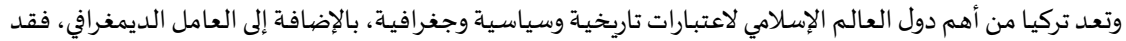

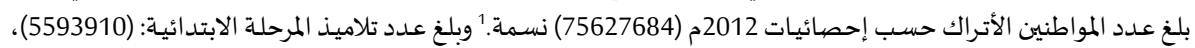

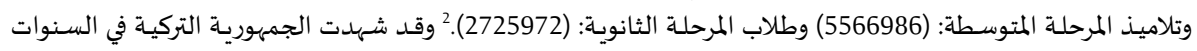

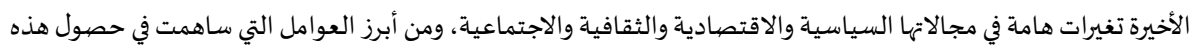

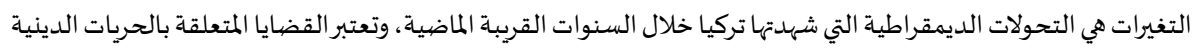

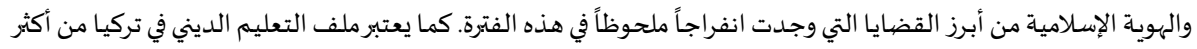

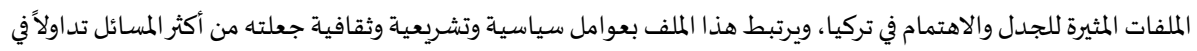

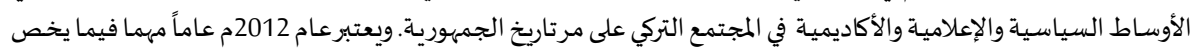

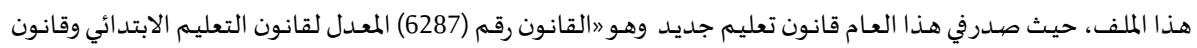

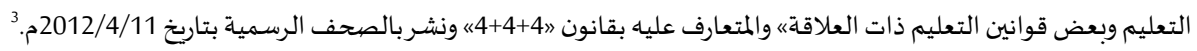

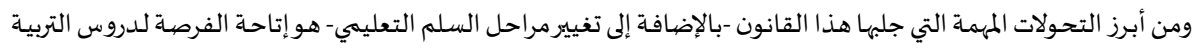

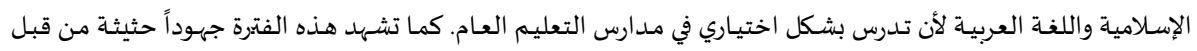

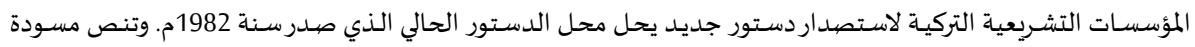

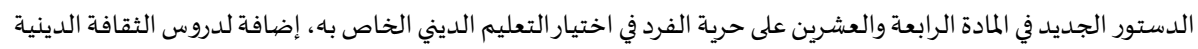

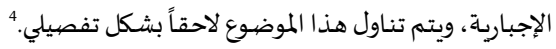

1 Istatistiklerle Türkiye 2012, Türkiye İstatistik Kurumu, Türkiye İstatistik Kurumu Matbaası, 2013, s. 9.

2 İstatistiklerle Türkiye 2012, Türkiye İstatistik Kurumu, Türkiye İstatistik Kurumu Matbaası, 2013, s. 25.

3 Recep Kaymakcan ve diğerleri, Seçmeli Din Eğitimi Dersleri İnceleme ve Değerlendirme Raporu, Çınar Basım Yayın, İstanbul, 2013, s: 3.

4 Yeni Anayasa'da Dini Kurumlar Din Eğitimi Ve Öğretimi Raporu, Ensar Vakfi, İstanbul, 2012, s: 14 . 


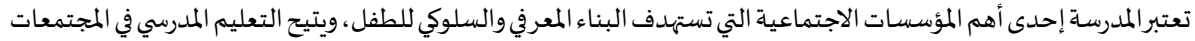

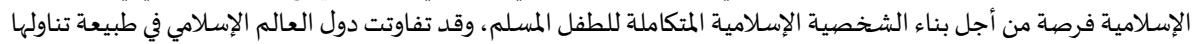

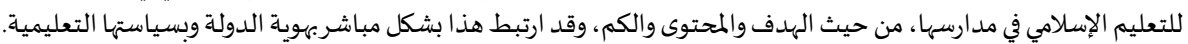

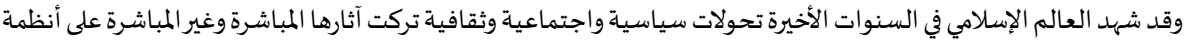

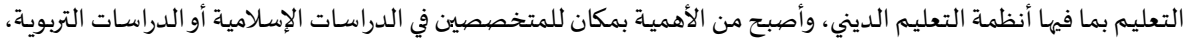

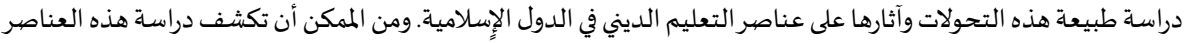

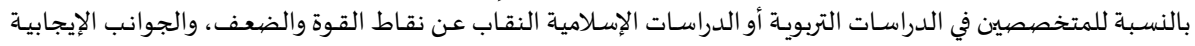

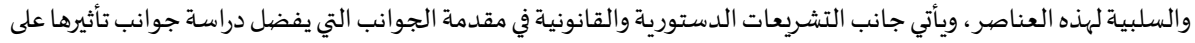

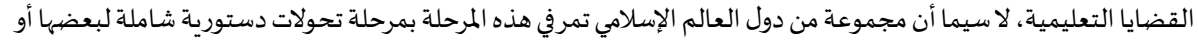

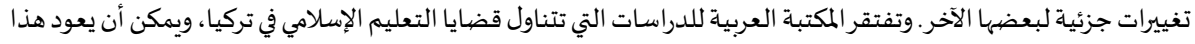

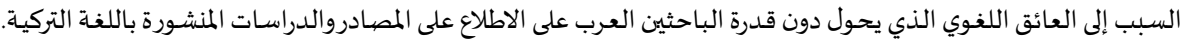

ويمكن القول بأن هذه الدراسة تستهدف الإجابة عن السؤ الئن الين التاليين:

1. ما العلاقة بين اتجاهات السياسة الداخلية وعناصر التعليم الديني في المدارس النظامية في تركيا؟.

2. ما التغيرات المعاصرة التي طرأت على نظام التعليم الديني في تركيا؟.

منهجية الدراسة ومحدداتها

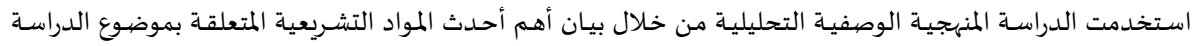

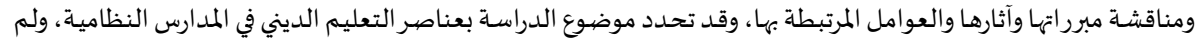

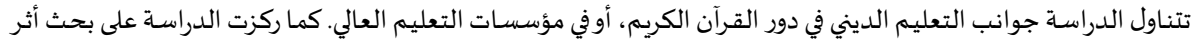

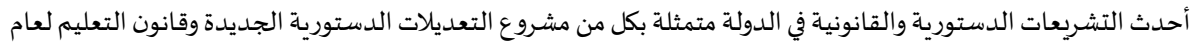
2012، وما تبعها من تغيرات عناصر التعليمات التورنيم الديني.

الدراسات السابقة

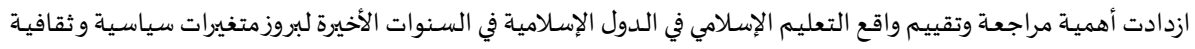

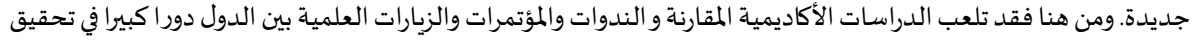

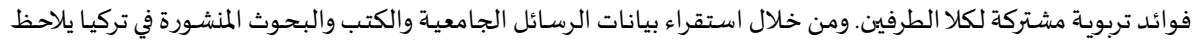

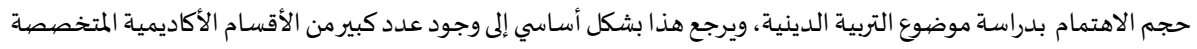

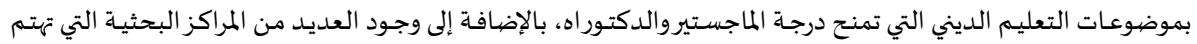

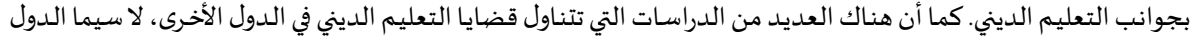

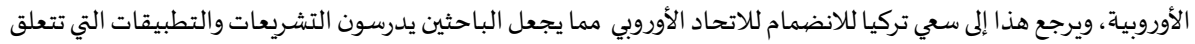

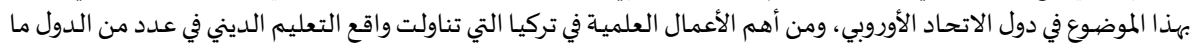

$$
\text { 1. }
$$

5 Halis Ayhan, Türkiye'de Din Eğitimi, İstanbul: M.Ü.İ.F Vakfı Nu.173, 1999.

6 Recep Kaymakcan, Günümüz İngiltere'sinde Din Eğitimi, 1.baskı, İstanbul: Değerler Eğitim Merkezi, 2004 


$$
\begin{aligned}
& \text { 3. التربية الدينية في ألمانيا الاتحادية.7 } \\
& \text { 4. التربية الدينية في هولندا.8 } \\
& \text { 5. التعليم الديني في المرحلة الابتدائية والمتوسطة في تونس.9 } \\
& \text { 6. التربية الدينية والأخلاقية في المرحلة الابتدائية في بلجيكا.10 } \\
& \text { 7. التربية الدينية في الأردن. } 11
\end{aligned}
$$

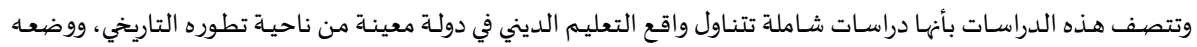

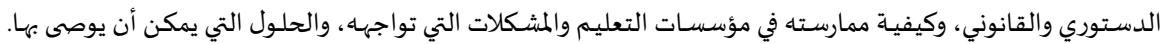
أما فيما يخص موضيوع الدراسـة فيما يتعلق بمشروع التعديلات الدستورية الأخيرة في تركيا وقانون التعليم لعام 2012م وأثرهما

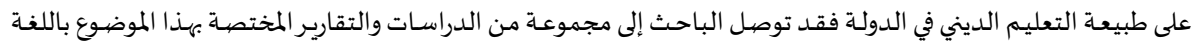
التركيـة، ومن أهمها ما يلي:

1. تقريربعنوان: هالمؤسسات الدينية والتعليم الديني في الدستور الجديد "Yeni Anayasa'da Dini Kurumlar)

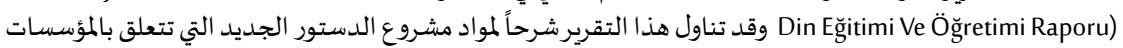

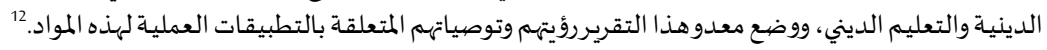

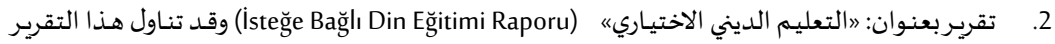

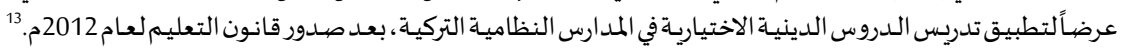
3. دراسـة بعنـوان: لاتقييمـات وتوصيـات متعلقـة بالقانون المعـدل لقانـون التعليم الأسـاسي وقانـون التعليم

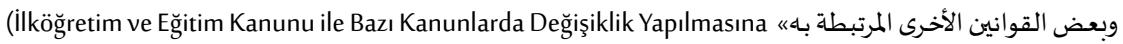
إسوان Bazı Değerlendirme ve Öneriler) Dair Kanun Teklifi Hakkında

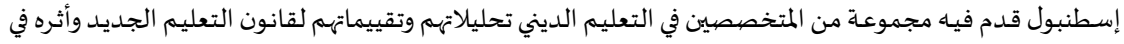
عناصـر التعليم الديني.

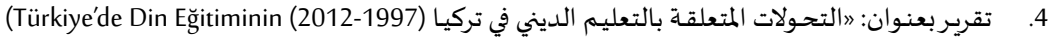

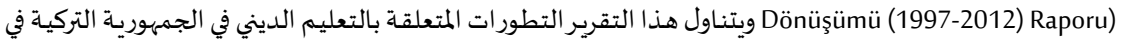

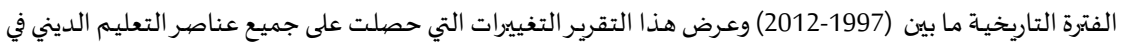

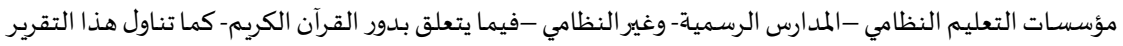

İrfan Başkurt, "Federal Almanya'da Din Eğitimi”, Marmara Üniversitesi Sosyal Bilimler Enstitüsü (Yayınlanmamış Yüksek Lisans Tezi), 1994.

8 M.Besim İsmailefendioğlu, "Hollanda'da Din Eğitimi", Marmara Üniversitesi Sosyal Bilimler Enstitüsü (Yayınlanmamış Doktora Tezi), 1997.

9 Mehmet Zeki Aydın, “Tunus'ta İlk ve Orta Dereceli Okullardaki Din Öğretimi Programları”, CÜ İlâhiyat Fakültesi Dergisi, S.2,1998, s.263-284.

10 Aydın, “Tunus'ta İlk ve Orta Dereceli Okullardaki Din Öğretimi Programları”, s.263-284.

11 Mohammad Thalgi, “Ürdün'de Din Eğitimi”, Marmara Üniversitesi Sosyal Bilimler Enstitüsü (Yayınlanmamış Doktora Tezi), 2007.

12 Yeni Anayasa'da Dini Kurumlar Din Eğitimi Ve Öğretimi Raporu , s: 14.

13 İsteğe Bağı Din Ĕ̆itimi Raporu, Ensar Vakfi, İstanbul, 2012, s: 21.

14 İlköğretim ve Eğitim Kanunu İle Bazı Kanunlarda Değişiklik Yapılmasına Dair Kanun Teklifi Hakkında Bazı Değerlendirme Ve Öneriler (4+4+4 Eğitim Sistemi), s: 8. 


$$
\text { الجوانب المتعلقـة بالتعليم الديني على مستوى الدراسـات العليا في تلك الفترة. } 15
$$

5. دراسـة بعنوان: لمـدارس الأئمـة والخطبـاء ومؤسسـة رئاسـة الشـؤون الدينيـة كنموذجين لعلاقـة الدولـة

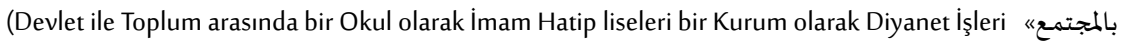
مaşkanlığوا وقد عرض الباحث في هذه الدراسة تاريخ مدارس الأئمة والخطباء ومؤسسة رئاسة الشؤون الدينية في تركيا

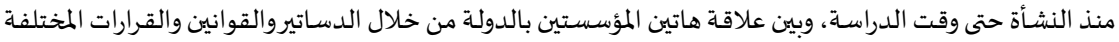
على مرتاريخ الجمهوريـة.

\section{أولا: لمحة تاريخية عن الظروف السياسية والتشريعية التي أثرت على التعليم الديني في الجمهورية التركية}

يتميزتاريخ التشـريعات التركيـة المتعلقـة بالتعليم الديني بارتباطه بعوامل السياسـة الداخليـة للدولة وهويتها السياسية أكثري

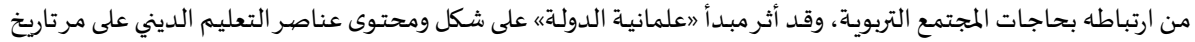

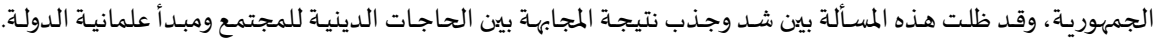

فبعدد إعلان تأسيس الجمهورية التركية بتاريخ 1923/10/29م اتخذت مجموعـة من التشريعات الدستورية والقانونية

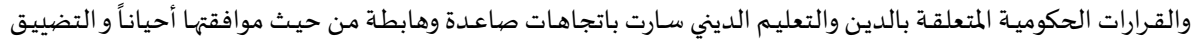

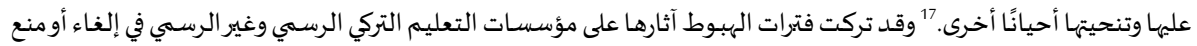

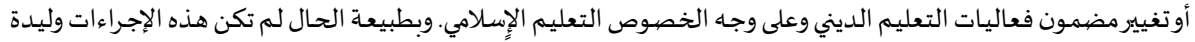

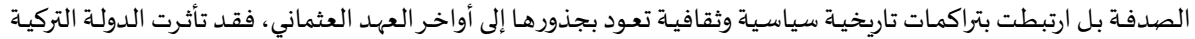

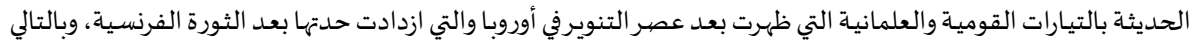

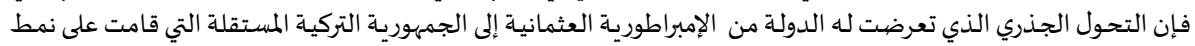
الدول القومية في أوروبا والتغييرات الثقافية والسياسية التي تلت ذلك قد ساهمت فئ في تكوين هوية جديدة للدية للمجتمع التركي.

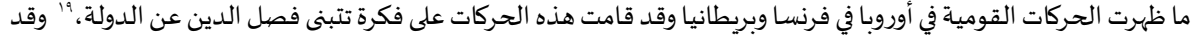
تبنت الدولة التركية الحديثة نموذج نظام دولة التهات يقوم على الأسـاس القومي و التغربي العلماني.

وقد شهدت الدولـة التركيـة في بعض الفترات التاريخيـة إجـراءات متشــددة تتعلق بالتدين والتعليم الديني، من الأمثلة

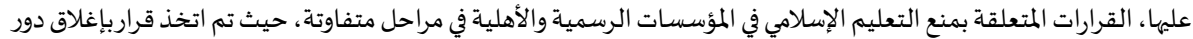

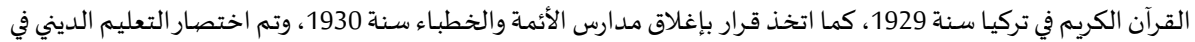

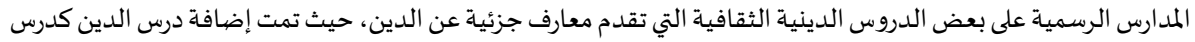

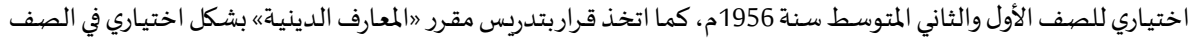

15 Bahçekapılı ve diğerleri, Türkiye'de Din Eğitiminin Dönüşümü (1997-2012) Raporu, İLKE İlim Kültür Eğitim Derneği, İstanbul 2012, s: 192.

16 İran Bozan, Devlet ile Toplum arasinda bir Okul olarak Imam Hatip liseleri bir Kurum olarak Diyanet İşleri Başkanlı̆̆ı, Tesev Yayınları, İstanbul, 2007, s: 11.

17 Medine Sevim, Türkiye'de Cumhuriyet Dönemi Din Eğitimi ve Öğretimi Kronolojisi, Dem dergi, say1:2, 2011, 64-71

18 Tuğça Poyraz ve Gülay Arıkan, Avrupa-Türkiye Ilişkileri ve Avrupa Yayılmacılığından Sonra Değişen “Öteki” Tanımları, Hacettepe Üniversitesi Edebiyat Fakültesi Dergisi, 2004 / cilt: 21 / sayi: 2 / ss. 1-16

19 Poyraz, Tuğça ve Gülay Arıkan, Avrupa-Türkiye Ilişkileri ve Avrupa Yayılmacılığından Sonra Değişen “Öteki” Tanımları, ss. 1-16

20 Süleyman Yıldız, Süleyman Yıldız, Kimlik Ve Ulusal Kimlik Kavramlarinin Toplumsal Niteliği, Millî Folklor, 2007, Y1l 19, Say: 74, s.9-16 
الرابع والصيف الخامس، ثم اتخذ قراربتدريس المعارف الدينية للصفين الأول والثاني سنة 1967م.21

وقد نص الدستور التركي لسنة 1982 في المادة الرابعة والعشرين على إجبارية درس »الثقافة الدينية والمعارف الأخلاقية《ه

في المـدارس التركيـة. وتم تدريس مـادة التربيـة الدينيـة في المـدارس التركيـة في المرحلـة الأسـاسية ابتـاء من الصـف الرابع بواقـع

حصتين أسبوعيا. 22

ويمكن القول بأن درس »الثقافة الدينية والمعارف الأخلاقياةه المدرس في المدارس التركية لا يعتبردرسا للتربية الإسلامية

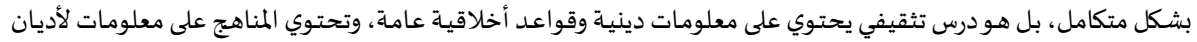

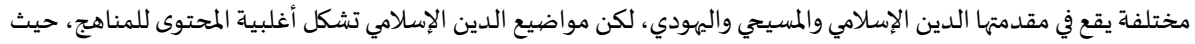

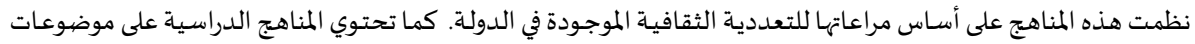

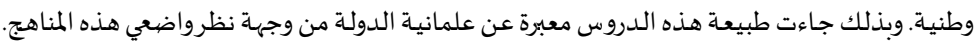

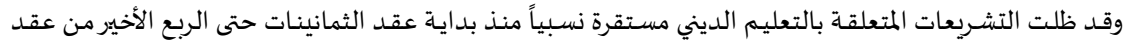

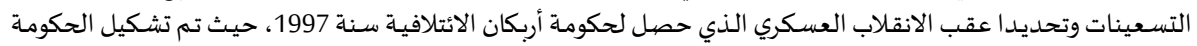

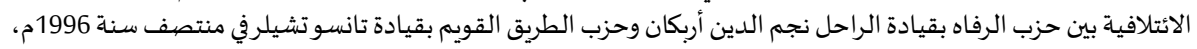

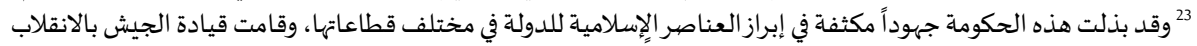

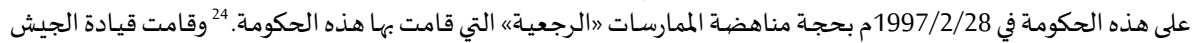

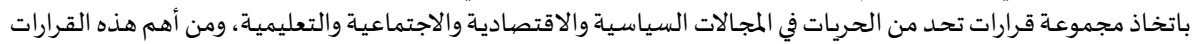

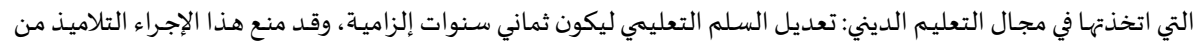

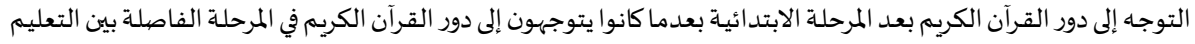

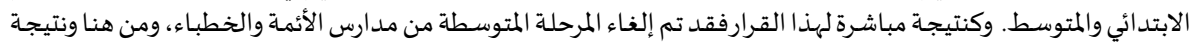

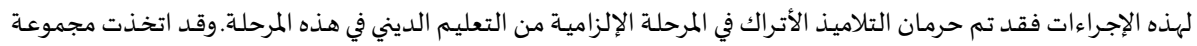

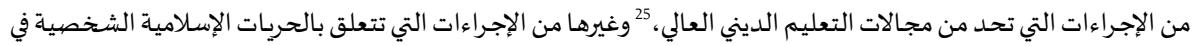

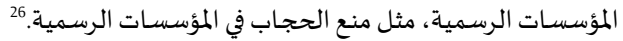

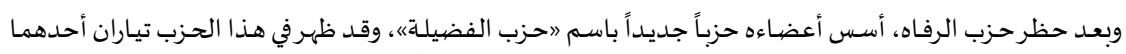

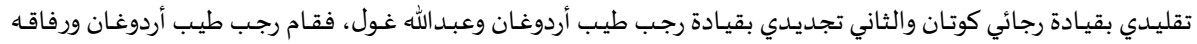

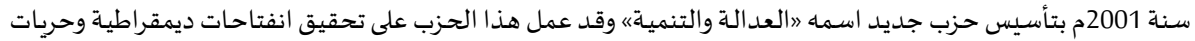

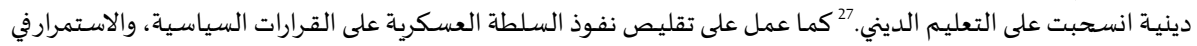

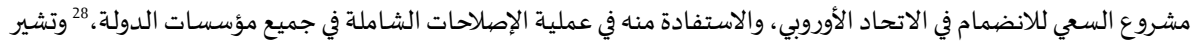

21 Sevim, Türkiye'de Cumhuriyet Dönemi Din Ĕgitimi ve Öğretimi Kronolojisi, 64-71 .

22 Sevim, Türkiye'de Cumhuriyet Dönemi Din Eğitimi ve Öğretimi Kronolojisi, 64-71 .

23 Bahçekapılı ve diğerleri, Türkiye'de Din Eğitiminin Dönüşümü (1997-2012) Raporu, s:35 .

24 Bahçekapılı ve diğerleri, Türkiye’de Din Eğitiminin Dönüşümü (1997-2012) Raporu, 62-69.

25 Bahçekapılı ve diğerleri, Türkiye'de Din Eğitiminin Dönüşümü (1997-2012) Raporu, s: 7085.

26 Cemal Karakas, "Turkey: Islam and Laicism Between the Interests of State, Peace Research Institute Frankfurt (PRIF) 2007, p. 27 Society", 1-41.

27 Senem Aydin and Ruşen Çakır, Political Islam in Turkey, Center for European Policy, .26 265 (2007): 1-12. 


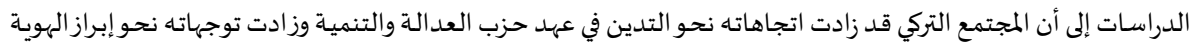

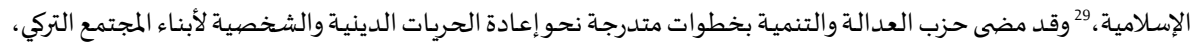

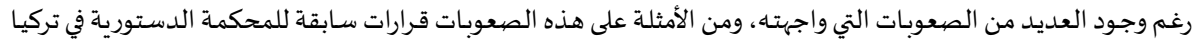

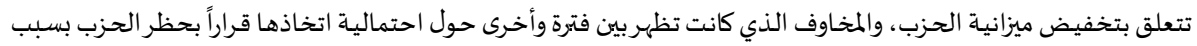

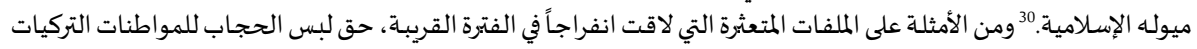

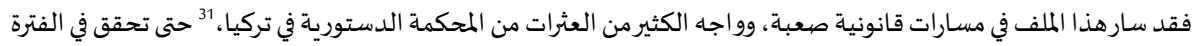

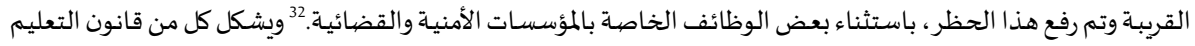

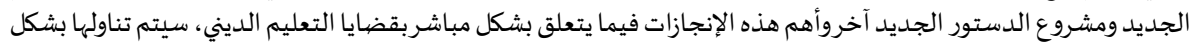
تفصيلي في هذه الدراسـة.

ثانيا: التعليم الديني في مشروع الدستور التركي الجديد

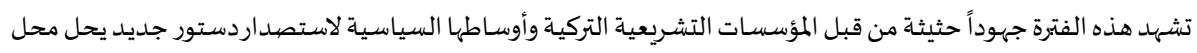

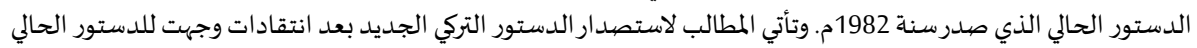

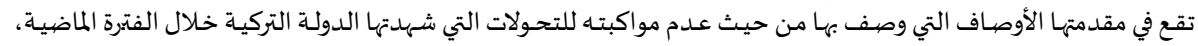

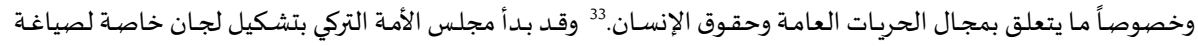

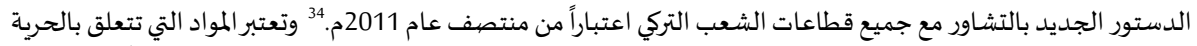

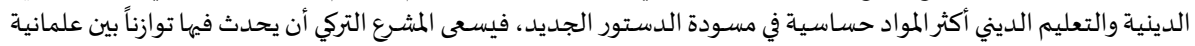

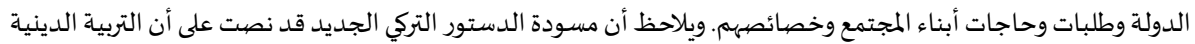

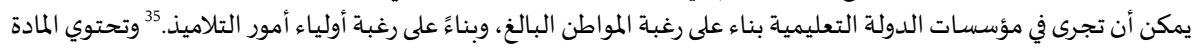

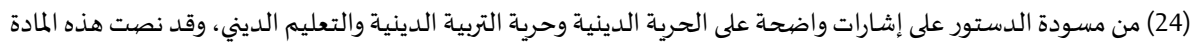

على ما يلي:

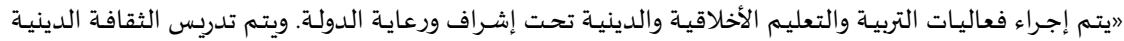

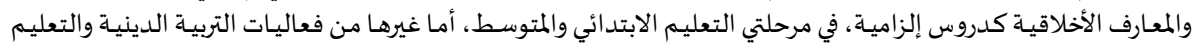

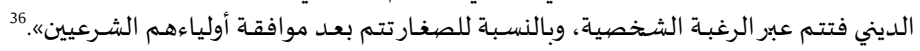

$$
\text { 1. }
$$

29 Derya Demirler, Değişen Türkiye'de Din Toplum Ve Siyaset, Tesev Yayınları, İstanbul, 2006, s.94.

خالد محمد أبو الحسن، محددات الصراع العلماني مع حزب العدالة في تركيا وآفاقه، مجلة دراسات شرق أوسطية، مجلد: 12، العدد

(47-46)

31 Zühtü Arslan, Başörtüsü, Ak Parti ve Laiklik: Anayasa Mahkemesinden İki Karar Bir Gerekçe, S E TA, Say1: 2 । Ocak, 2009, s. 3-25.

32 http://www.sabah.com.tr/Gundem/2013/09/30/basostusu-yasagi-kalkiyor.

33 Yeni Anayasa'da Dini Kurumlar Din Eğitimi Ve Öğretimi Raporu , s: 14.

34 Etyen Mahçupyan ve Diğerleri, Yeni Anayasa Sürecini İzleme Raporu: Nasıl Bir Anayasaya Doğru Gidiyoruz, Tesev Demokratikleşme Programı, 2013, s:1.

35 İsteğe Bağlı Din Eğitimi Raporu, s: 21.

36 İsteğe Bağlı Din Eğitimi Raporu, s: 21. 
3. أن تكون دروس التربية والتعليم الديني الأخرى -خارج دروس 》الثقافة الدينية والمعارف الأخلاقيـة《اختياريـة.

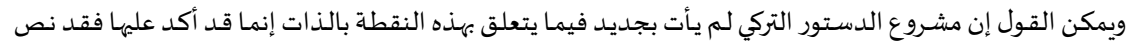

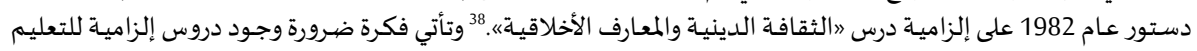

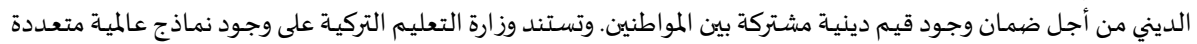

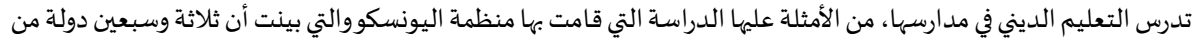

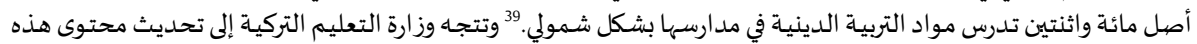

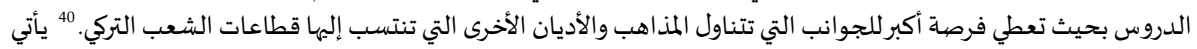

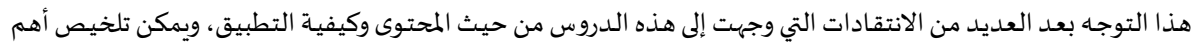

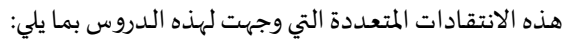

أولا: أن هذه الدروس تستهدف تقديم معرفة مجردة أكثير من استهدافها لمهارات تطبيقية للتلميذ، كما أن المعرفة التي تحتوها لا تلبي حاجات التلميذ.

ثانيا: تم انتقاد هذه الدروس من قبل أتباع الطائفة العلوية، حيث طالبوا بعدم إلزام أبناءهم بهده الدروس لأنها لا تتناسب مع معتقدات طائفتهم.

ثالثا: اعترض المواطنين الأتراك من الأديان الأخرى على محتوى المقرر الذي يتناول في أغلبه موضوعات الدين الإسلامي.41

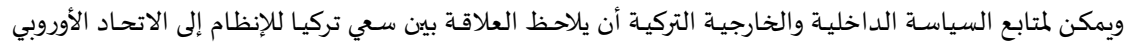

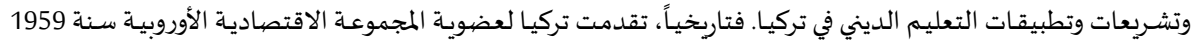

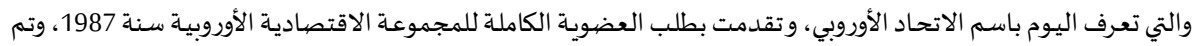

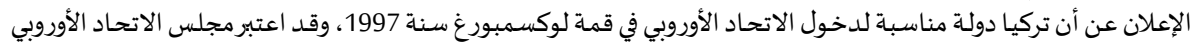

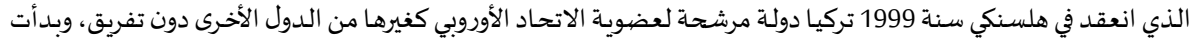

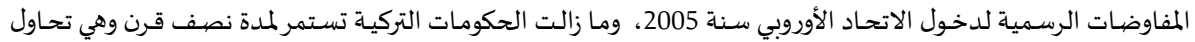

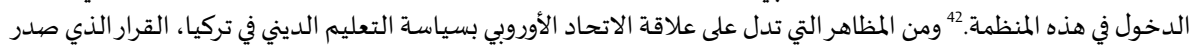

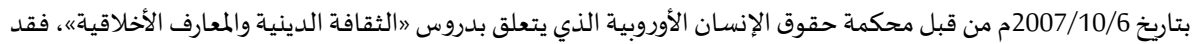

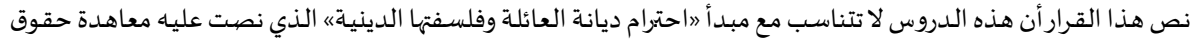

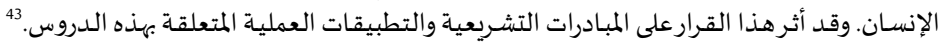

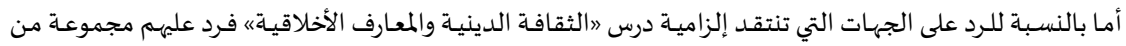

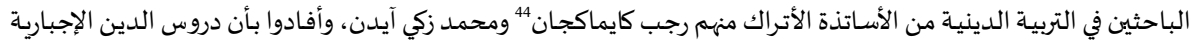

Yeni Anayasa'da Dini Kurumlar Din Eğitimi Ve Öğretimi Raporu , s: 16.

38 İsteğe Bağlı Din Eğitimi Raporu, s: 20.

39 İsteğe Bağlı Din Eğitimi Raporu, s: 21.

40 İsteğe Bağlı Din Eğitimi Raporu, s: 25.

41 İsteğe Bağlı Din Eğitimi Raporu, s: 20.

42 Uluslararası Azınlık Hakları Grubu 2007, Bir Eşitlik Arayışı: Türkiye'de Azınlıklar, United Kingdom, London, 2007.

43 Recep Kaymakcan, AIHM Din Dersi Kararı Nasıl Anlaşılmalı, DEM Dergi, Y1l 1 Sayı 2, 2007.

44 Recep Kaymakcan ve diğerleri, Seçmeli Din Eğitimi Dersleri İnceleme ve Değerlendirme Raporu, s: 3 . 


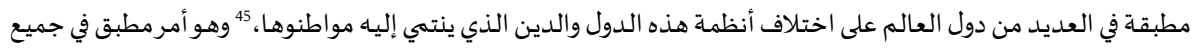

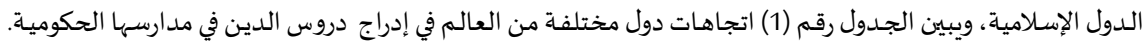

جدول (1) اتجاهات عدد من دول العالم في تدريس دروس الدين في مدارسها الحكومية

\begin{tabular}{|c|c|c|c|}
\hline لا يوجد دروس دين & دروس الدين اختيارية & دروس دين إجبارية أودرس & دروس دين إجبارية \\
\hline $\begin{array}{c}\text { الولايات المتحدة الأمريكية } \\
\text { اليابان }\end{array}$ & البرال البرتراليا & فلبلجيكا & الدول الإسلامية \\
\hline
\end{tabular}

Mehmet Zeki Aydın, Yeni Anayasa ve Din Dersi Tartışmaları, Düşünce Platformu Dergisi, Ankara 2008, yıl:3, sayı:30, ss.120-125

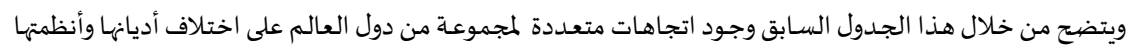

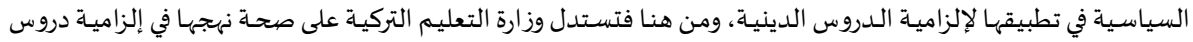

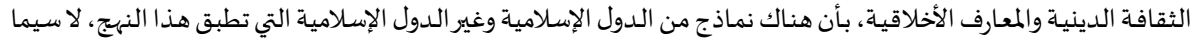

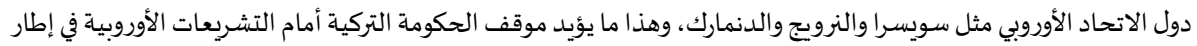
سعيها للانضمام في الاتحاد الأوروبي.

أما فيما يتعلق بالدروس الاختيارية، فقد بدأ الجدال المتعلق بمدى إمكانية تقديم دروس تربية دينية اختيارية في المدارس المارس

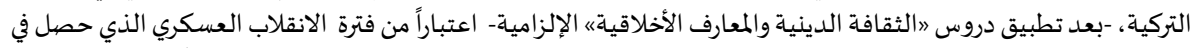

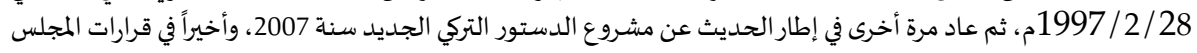
الاستشاري للتعليم القومي الثامن عشر عام في إطار 2010م.

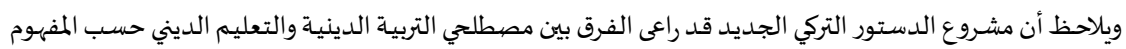

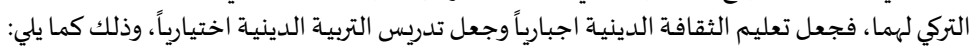

1. نصت مسودة الدستور على أن دروس التعليم الديني (Din Öğretimi) المختصهة بتقديم المعرفة والثقافة الدينيـة والأخلاقيـة هي دروس إلزاميـة.

2. غيرهذه الدروس من فعاليات التربية الدينية (Din Eğitimi) والتعليم الديني (Din Öğretimi) فتتم عبر

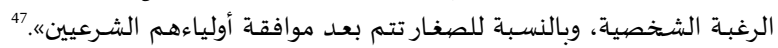

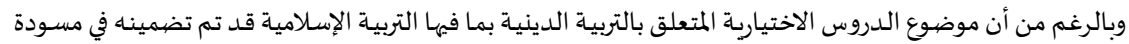

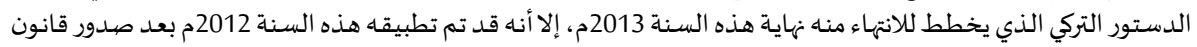

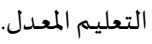

45 Mehmet Zeki Aydın, Yeni Anayasa ve Din Dersi Tartışmaları, Düşünce Platformu Dergisi, Ankara 2008, y11:3, say1:30, ss.120-125

46 İsteğe Bağlı Din Eğitimi Raporu, s: 20.

47 İsteğe Bağlı Din Eğitimi Raporu, s: 21. 
ثالثاً: التعليم الديني في قانون التعليم لعام 2012

بدأ العمل بتطبيق 》القانون رقم (6287) المعدل لقانون التعليم الابتدائي وقانون التعليم وبعض قوانين التعليم ذات العلاقةة)

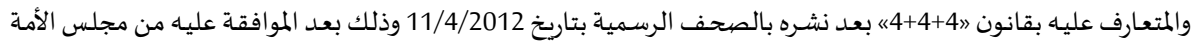

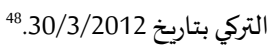

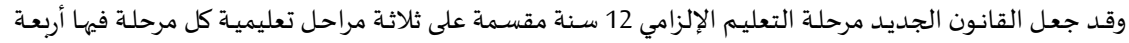

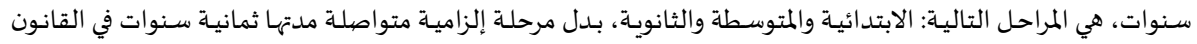

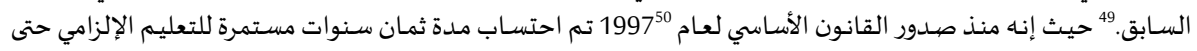

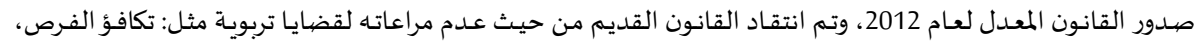

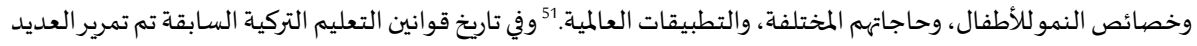

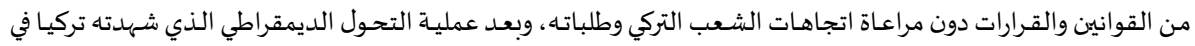

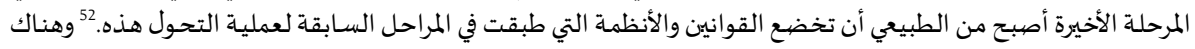

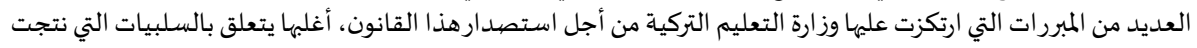

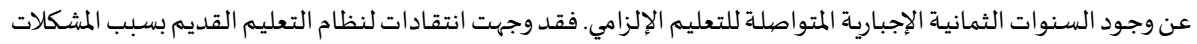

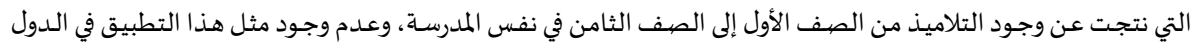

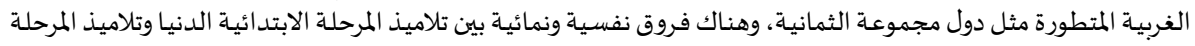

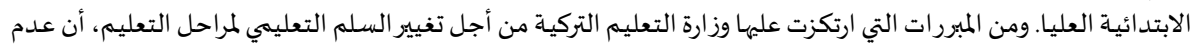

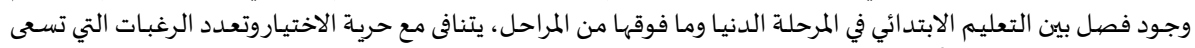

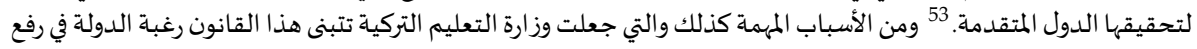

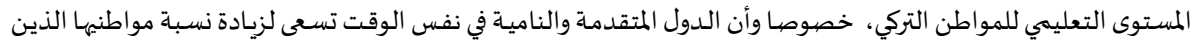

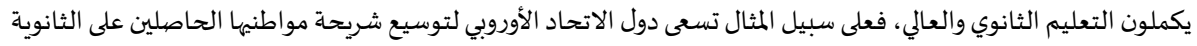

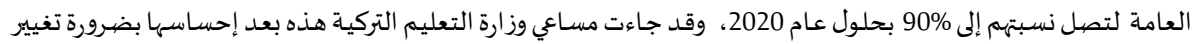

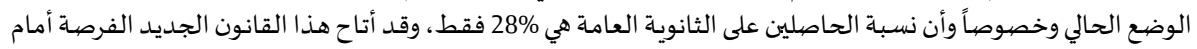

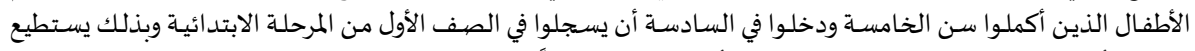

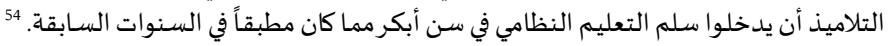

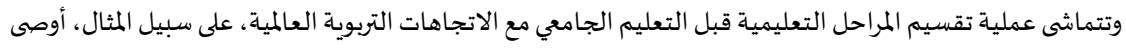

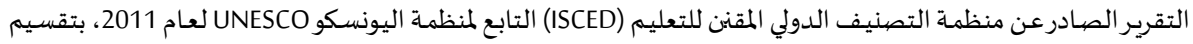

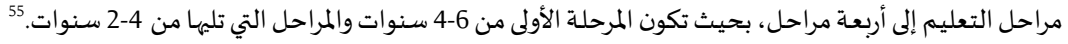

2012 - 2013 Eğitim- Öğretim Yılı 4+4+4 Zorunlu Eğitim Yasasıyla Başlıyor, Eğitim ve Bilim İş Görenleri Sendikas1, Ağustos 2012, s:2.

49 İlköğretim ve Eğitim Kanunu İle Bazı Kanunlarda Değişiklik Yapılmasına Dair Kanun Teklifi Hakkında Bazı Değerlendirme Ve Öneriler (4+4+4 Eğitim Sistemi), Ensar Vakfi, İstanbul, 2012, s: 8 .

51 İlköğretim ve Eğitim Kanunu İle Bazı Kanunlarda Değişiklik Yapılmasına Dair Kanun Teklifi Hakkında Bazı Değerlendirme Ve Öneriler (4+4+4 Eğitim Sistemi) , s: 7.

52 İlköğretim ve Eğitim Kanunu İle Bazı Kanunlarda Değişiklik Yapılmasına Dair Kanun Teklifi Hakkında Bazı Değerlendirme Ve Öneriler (4+4+4 Eğitim Sistemi), s: 7.

53 İlköğretim ve Eğitim Kanunu İle Bazı Kanunlarda Değişiklik Yapılmasına Dair Kanun Teklifi Hakkında Bazı Değerlendirme Ve Öneriler (4+4+4 Eğitim Sistemi), 2012, s: 8.

5412 Yil Zorunlu Eğitim Sorular - Cevaplar, T. C. Millî Eğitim Bakanliği, Ankara, 2012, s, 8-10.

55 İlköğretim ve Eğitim Kanunu İle Bazı Kanunlarda Değişiklik Yapılmasına Dair Kanun Tek- 


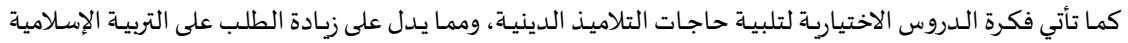

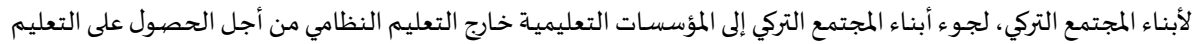

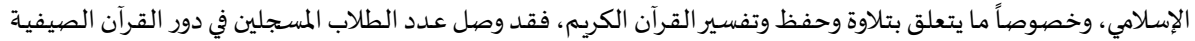

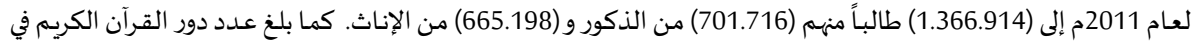

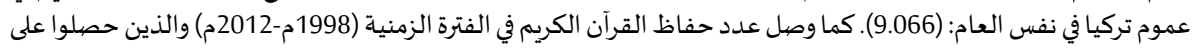

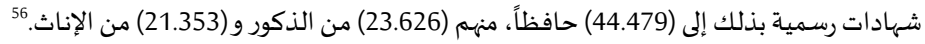

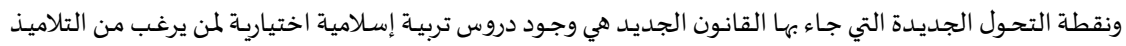

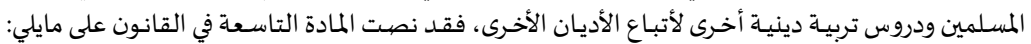

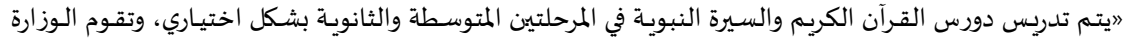

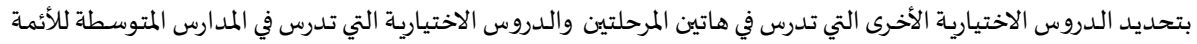

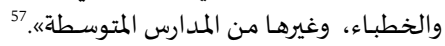

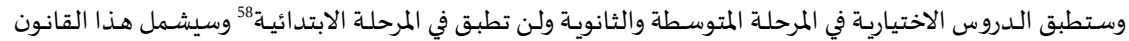

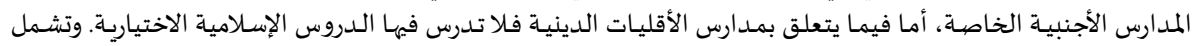

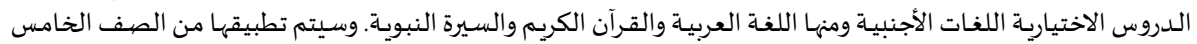

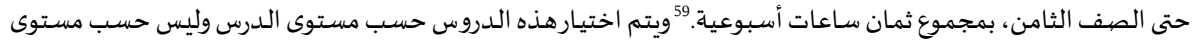

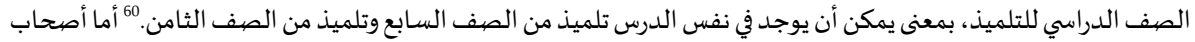

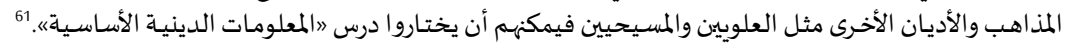

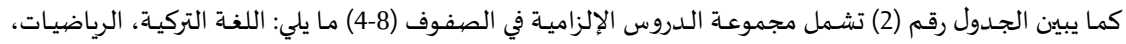

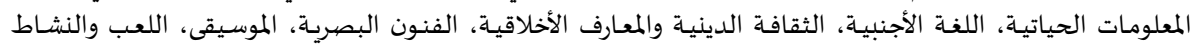

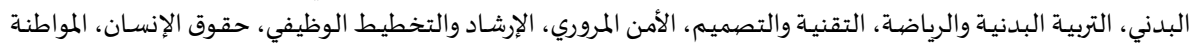
والديمقراطية.

lifi Hakkında Bazı Değerlendirme Ve Öneriler (4+4+4 Eğitim Sistemi), 2012, s: 8.

56 Bahçekapılı ve diğerleri, Türkiye'de Din Eğitiminin Dönüşümü (1997-2012) Raporu, s: 89-105.

57 http://www.resmigazete.gov.tr/eskiler/2012/04/20120411-8.htm.

5812 runlu Eğitim Sorular - Cevaplar, T. C. Millî Eğitim Bakanliği, Ankara, 2012, s: 23.

5912 Ynzorunlu Eğitim Sorular - Cevaplar, T. C. Millî Eğitim Bakanliği, Ankara, 2012, s: 24.

60 Bahçekapılı ve diğerleri, Türkiye'de Din Eğitiminin Dönüşümü (1997-2012) Raporu, s: 192.

6112 Yil Zorunlu Eğitim Sorular - Cevaplar, T. C. Millî Eğitim Bakanliği, Ankara, 2012, s: 24.

6212 Yil Zorunlu Eğitim Sorular-Cevaplar, T. C. Millî Eğitim Bakanliği, Ankara, 2012, s: 24. 
جدول (2) الدروس الإلزامية في المرحلتين الابتدائية والمتوسطة

\begin{tabular}{|c|c|c|c|c|c|c|c|c|c|}
\hline \multicolumn{8}{|c|}{ الصفوف } & \multirow{3}{*}{\multicolumn{2}{|c|}{ 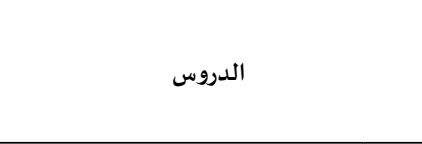 }} \\
\hline \multicolumn{4}{|c|}{ المرحلة المتوسطة } & \multicolumn{4}{|c|}{ المرحلة الابتدائية } & & \\
\hline 8 & 7 & 6 & 5 & 4 & 3 & 2 & 1 & & \\
\hline 5 & 5 & 6 & 6 & 8 & 8 & 10 & 10 & اللغة التركية & \\
\hline \multirow[t]{2}{*}{5} & 5 & 5 & 5 & 5 & 5 & 5 & 5 & الرياضيات & \\
\hline & & & & & 3 & 4 & 4 & المعلومات الحياتية & \\
\hline \multirow[t]{2}{*}{4} & 4 & 4 & 4 & 3 & 3 & & & 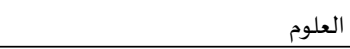 & \\
\hline & 3 & 3 & 3 & 3 & & & & الاجتماعيات & \\
\hline 2 & & & & & & & & التحول الجمهوري والأتاتوركية & \\
\hline 4 & 4 & 4 & 4 & 2 & 2 & 2 & & اللغة الأجنبية & $\overline{3}$ \\
\hline 2 & 2 & 2 & 2 & 2 & & & & الثقافة الدينية والمعارف الأخلاقية & 3 \\
\hline 1 & 1 & 1 & 1 & 1 & 1 & 1 & 1 & الفنون البصرية & $\frac{7}{9}$ \\
\hline \multirow[t]{2}{*}{1} & 1 & 1 & 1 & 1 & 1 & 1 & 1 & الموسيقى & \\
\hline & & & & 2 & 5 & 5 & 5 & اللعب والنشاط البدني & \\
\hline 2 & 2 & 2 & 2 & & & & & التربية البدنية والرياضة & \\
\hline \multirow[t]{2}{*}{2} & 2 & & & & & & & التقنية والتصميم & \\
\hline & & & & 1 & & & & 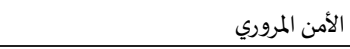 & \\
\hline \multirow[t]{2}{*}{1} & & & & & & & & الإرشاد والتخطيط الوظيفي & \\
\hline & & & & 2 & & & & حقوق الإنسان والمواطنة والديمقراطية & \\
\hline 29 & 29 & 28 & 28 & 30 & 28 & 28 & 26 & الدروس الإجبارية & 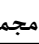 \\
\hline
\end{tabular}

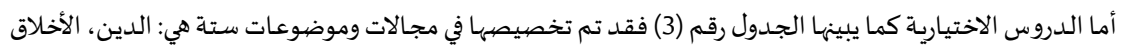

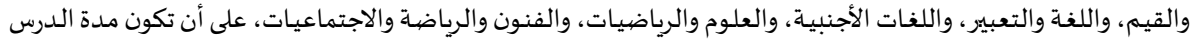

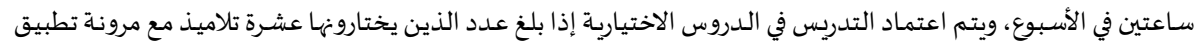

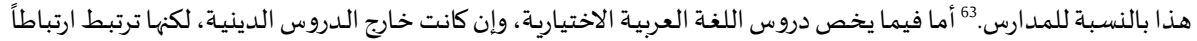

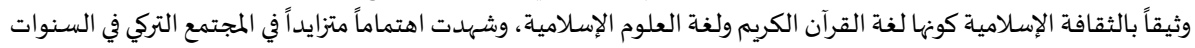

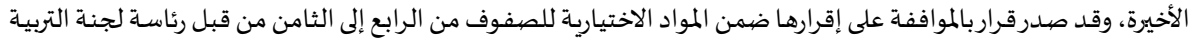

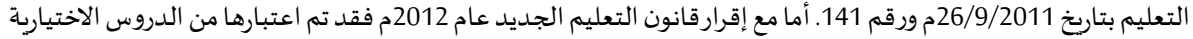
التي تدرس بعد الصـف الرابع الابتدائي بواقع سـاعتين أسبوعيتين.

6312 Yil Zorunlu Eğitim Sorular - Cevaplar, T. C. Millî Eğitim Bakanliği, Ankara, 2012, s: 24.

64 Bahçekapılı ve diğerleri, Türkiye'de Din Eğitiminin Dönüşümü (1997-2012) Raporu, s: 193. 
جدول (3) الدروس الاختيارية في المرحلتين الابتدائية والمتوسط

\begin{tabular}{|c|c|c|c|c|c|c|c|c|c|c|}
\hline \multicolumn{8}{|c|}{ الصفوف } & \multirow{3}{*}{\multicolumn{3}{|c|}{ 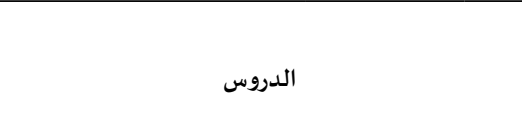 }} \\
\hline \multicolumn{2}{|c|}{ المتوسطة } & \multicolumn{2}{|c|}{ 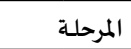 } & \multicolumn{4}{|c|}{ الابتدائية } & & & \\
\hline 8 & 7 & 6 & 5 & 4 & 3 & 2 & 1 & & & \\
\hline 2 & 2 & 2 & 2 & & & & & القرآن الكريم & \multirow{3}{*}{ والقيم الأخلاق } & \multirow{16}{*}{$\begin{array}{c}\overline{3} \\
\overline{3} \\
3 \\
\overline{3} \\
3 \\
3 \\
3\end{array}$} \\
\hline 2 & 2 & 2 & 2 & & & & & السيرة & & \\
\hline \multirow[t]{2}{*}{2} & 2 & 2 & 2 & & & & & معارف دينية أساسية & & \\
\hline & & 2 & 2 & & & & & مهارات القراءة & \multirow{4}{*}{ اللغة والتعبير } & \\
\hline 2 & 2 & 2 & 2 & & & & & مهارات الكتابة & & \\
\hline 2 & 2 & 2 & 2 & & & & & اللغات واللهجات المحكية & & \\
\hline 2 & 2 & 2 & 2 & & & & & مهارات العرض والاتصال & & \\
\hline 2 & 2 & 2 & 2 & & & & & مجلس الوزراء المقبولة حسب قرار & اللغنة & \\
\hline 2 & 2 & 2 & 2 & & & & & التطبيقات العلمية & \multirow{3}{*}{ والرياضيات } & \\
\hline 2 & 2 & 2 & 2 & & & & & التطبيقات الرياضية & & \\
\hline 2 & 2 & 2 & 2 & & & & & تكنولوجيا المملومات والبرمجيات & & \\
\hline $2 / 4$ & $2 / 4$ & $2 / 4$ & $2 / 4$ & & & & & الفنون البصرية & \multirow{5}{*}{ والفياضة } & \\
\hline $2 / 4$ & $2 / 4$ & $2 / 4$ & $2 / 4$ & & & & & الموسيقى & & \\
\hline $2 / 4$ & $2 / 4$ & $2 / 4$ & $2 / 4$ & & & & & الرياضية والنشاط & & \\
\hline & & 2 & 2 & & & & & 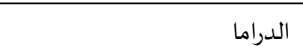 & & \\
\hline \multirow[t]{2}{*}{2} & 2 & 2 & 2 & & & & & ألعاب الذكاء & & \\
\hline & 2 & 2 & & & & & & الثقافة الشعبية & \multirow{4}{*}{ الاجتماعيات } & \\
\hline \multirow[t]{2}{*}{2} & 2 & & & & & & & الصحافة & & \\
\hline & 2 & 2 & & & & & & الحقوق والعدالة & & \\
\hline 2 & 2 & & & & & & & التربية الفكرية & & \\
\hline 8 & 8 & 8 & 8 & & & & & \multicolumn{3}{|c|}{ عدد الساعات التي يمكن اختيارها } \\
\hline
\end{tabular}

ويبين الجدول رقم (4) محتوى دروس الثقافة الدينية والمعارف الأخلاقية حسب الفصيول الدراسية والتي يبدأ تدريسها

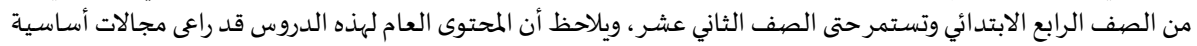

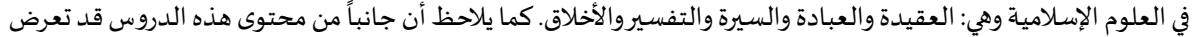
لمواضيع خارجة عن قضايا التعليم الإسلامي. 
جدول رقم (4) محتوى دروس الثقافة الدينية والمعارف الأخلاقية حسب الفصول الدراسية65

\begin{tabular}{|c|c|c|c|c|c|c|c|c|c|}
\hline 12 & 11 & 10 & 9 & 8 & 7 & 6 & 5 & 4 & \\
\hline التصالآنرة & والإندر & |الإيمان & 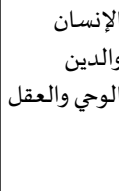 & والقدر & الآخر & السماوية والكتب & الإيمان بالله & عن معلومات & العقيدة \\
\hline 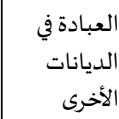 & الإسبادة في & |العبادة & والعبادة & والأزكاة والحجة & الصوم & الصلاة & معنى العبادة & الطهارة & العبادة \\
\hline شهمي & النبي القدوة & القرآني في & حياة النبي & النبي القدوة & البشر النبي & خاتم المرسلين & 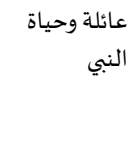 & محن سيدنات & السيرة \\
\hline & & |التفسير & & العقل & الفكر الإسلامي & القوضرآنات & التربية للقرآن & تعرف & التفسير \\
\hline والسالسلام & والدين & |الحقيق & لأخلاق & من السيئة العادات & الحميدة & السلوضيات التبل حذر الإسلام & $\begin{array}{r}\text { والأحزان الأفراح } \\
\text { والماركة }\end{array}$ & والألخدة & الأخلاق \\
\hline الألعض المصائص & والإسلام & |الإسلام & لإسلاك & الألمواليان & والدافننا & والأتساكلام & وأمتنا وطننا & والديائلة & والثقافة \\
\hline التعلينيم & الديهيد & |أتاتورك & لر لدين & & & & & & والدلمانية \\
\hline
\end{tabular}

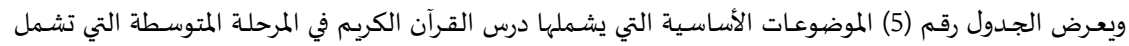

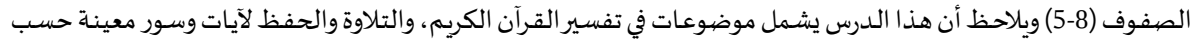
الصف الدراسي. 
جدول رقم (5) موضوعات درس القرآن الكريم في المرحلة المتوسطة66

\begin{tabular}{|c|c|c|c|c|}
\hline 8 & 7 & 6 & 5 & الموضعات/الصف \\
\hline الموضهوعات الرئيسة للقرآن & فهم إنشارات القرآن الكريم & تحسين & فهم إشـارات القرآن النريم & إشـارات القرآن الكريم \\
\hline 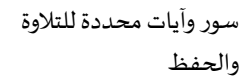 & سلتلاوة وآيات محددة & سلتلاور وآيات محددة & سلتلاور وآيات محددة & التلاوة والحفظ \\
\hline
\end{tabular}

كمـا يعرض الجـدول رقم (6) الموضيوعات التي يتناولها درس السيرة النبويـة في المرحلة المتوسطة والتي تشـمل الصفـوف

جدول رقم (6) موضوعات درس السيرة النبوية في المرحلة المتوسطة

\begin{tabular}{|c|c|c|c|c|}
\hline 8 & 7 & 6 & 5 & الموضعات/الصف \\
\hline قصص مختارة من & قصص مختارة من & قصص مختارة من & قصص مختارة من & قصص من حياة النبي \\
\hline السيرة & السيرة & السيرة & السيرة & \\
\hline الترفيه والرياضة & اللباس & تناول الطعام & النظافة & موضيوعات من السيرة \\
\hline 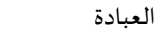 & الدعاء & العبادة & الأخلاق & النبي كقدوة للبشر \\
\hline تعامل النبي مع & عدالة النبي & تعامل النبي مع & تعامل النبي مع & الحياة الاجتماعية للنبي \\
\hline الأقارب & وظيفة الأم والأب & الأقارب & وظائف الأطفال & أسرة النبي \\
\hline علاقات النبي & تقوية الروابط & علاقات النبي & صحبة النبي & التواصل الاجتماعي في حياة \\
\hline الاجتماعية & الاجتماعية & الاجتماعية & & النبي \\
\hline
\end{tabular}

رابعاً: مدارس الأئمة الخطباء

تعود جذور هذه المؤسسة إلى "مدرسة الإرشاده في العهد العثماني التي أسست سنة 1913م، وكان هدفها تأهيل الأئمة والخطباء،

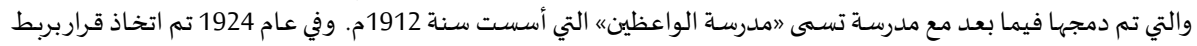

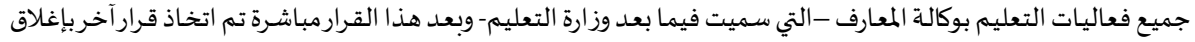

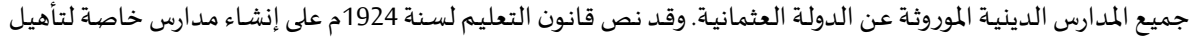

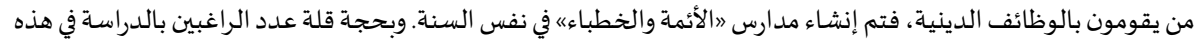

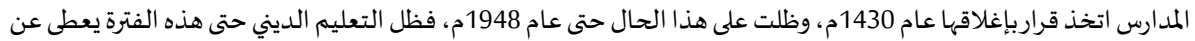

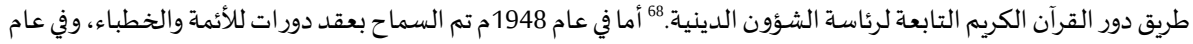

66 Bahçekapılı ve diğerleri, Türkiye'de Din Eğitiminin Dönüşümü (1997-2012) Raporu, s: 204.

67 Bahçekapılı ve diğerleri, Türkiye'de Din Eğitiminin Dönüşümü (1997-2012) Raporu, s: 206.

68 Bozan, Devlet ile Toplum arasında bir Okul olarak Imam Hatip liseleri bir Kurum olarak Diyanet 
1951م تم إعادة فتح مدارس الأئمة والخطباء بعد فوز الحزب الديمقراطي بانتخابات عام 1950م، في عدة مدن تركيـة، وكانت

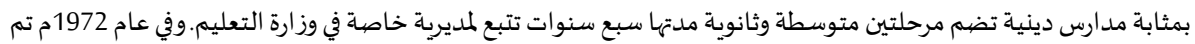

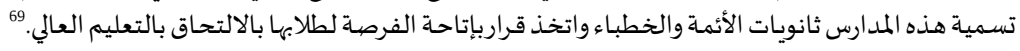

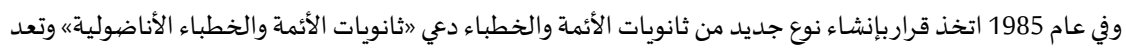

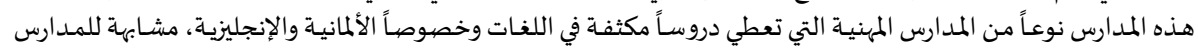

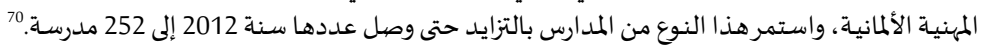

ومضت هذه المدارس في مسيرتها التعليمية عبر السنوات اللاحقة لكنها تعرضت لنوع من التضييقات خصوصاً فيما يتعلق

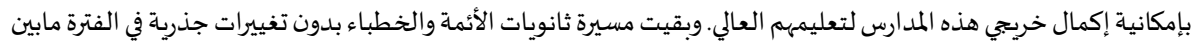

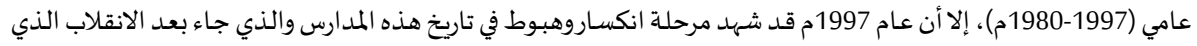

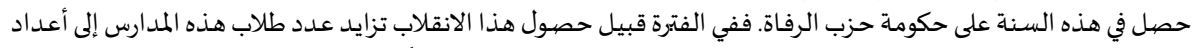

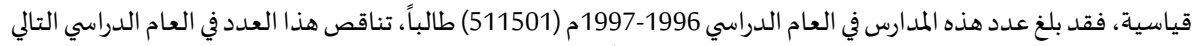

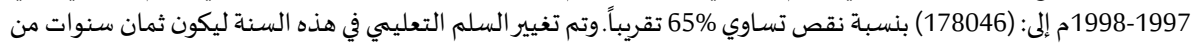

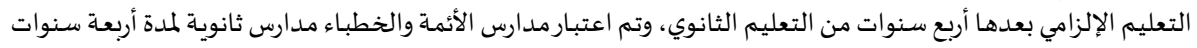

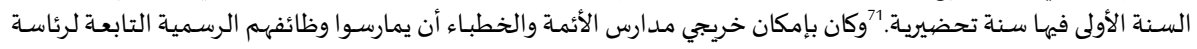

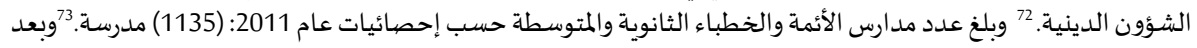

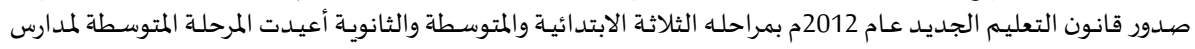
الأئمة والخطباء وأصبحت قانون التعم الجدئ المرحلة المتوسطة والثانوية. 74

جدول رقم (7) أعداد طلاب ومعلمين مدارس الأئمة والخطباء خلال ثلاثة أعوام دراسية

\begin{tabular}{|c|c|c|c|c|c|c|}
\hline المعلمين & نسبة الإناث & الإناث & نسبة الذكور & الذكور & مجموع العدد & العام الدراسي \\
\hline 10.617 & 52,54 & 104.339 & 47,46 & 94.242 & 198.581 & $2009-2010$ \\
\hline 12.909 & 52,09 & 122.713 & 47,81 & 112.651 & 235.639 & 2010-2011 \\
\hline 15.049 & 52,87 & 141.816 & 47,13 & 126.429 & 268.245 & 2011-2012 \\
\hline
\end{tabular}

Mehmet Bahçekapılı ve diğerleri, Türkiye'de Din Eğitiminin Dönüşümü (1997-2012) Raporu, İLKE İlim Kültür Eğitim Derneği, İstanbul 2012, s: 133.

İşleri Başkanlı̆̆ı, s. 13.

69 Bozan, Devlet ile Toplum arasinda bir Okul olarak Imam Hatip liseleri bir Kurum olarak Diyanet İşleri Başkanlı̆̆l, s: 14 .

70 Bahçekapılı ve diğerleri, Türkiye'de Din Eğitiminin Dönüşümü (1997-2012) Raporu, s: 117.

71 Bozan, Devlet ile Toplum arasinda bir Okul olarak Imam Hatip liseleri bir Kurum olarak Diyanet İşleri Başkanlı̆̆ı, s: 21-20.

72 Bozan, Devlet ile Toplum arasinda bir Okul olarak Imam Hatip liseleri bir Kurum olarak Diyanet İşleri Başkanlı̆̆ı, s: 33.

73 Bahçekapılı ve diğerleri, Türkiye'de Din Eğitiminin Dönüşümü (1997-2012) Raporu, s: 134.

74 http://www.resmigazete.gov.tr/eskiler/2012/04/20120411-8.htm. 


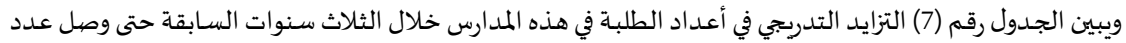

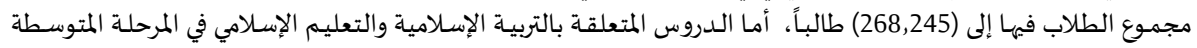

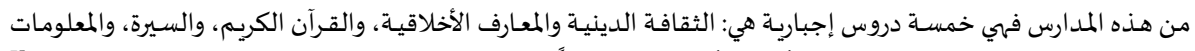

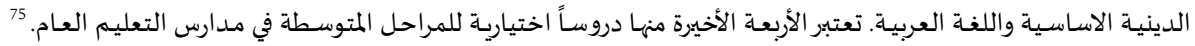

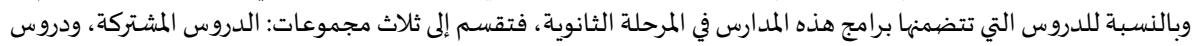

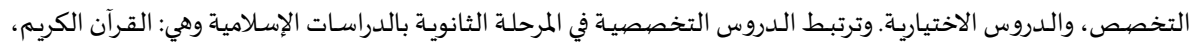

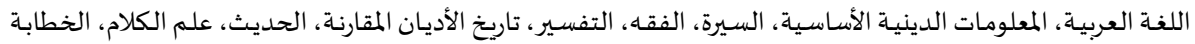
والتطبيقـات المهنيـة، التاريخ الإسـلامي.

وهناك العديد من الدراسـات التي تناولت العناصـر التعليمية المختلفة لمدارس الأئمة والخطباء، ففي دراسـة قام بها كل

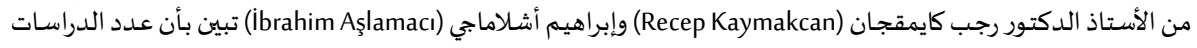

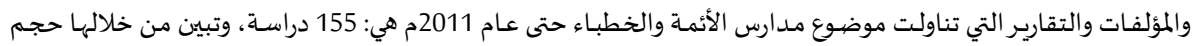

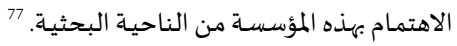

\section{سـادساً: تأهيل معلمي الدروس الدينية في المدارس النظامية}

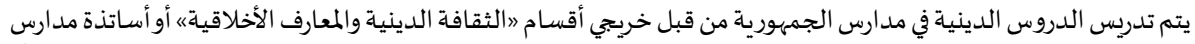

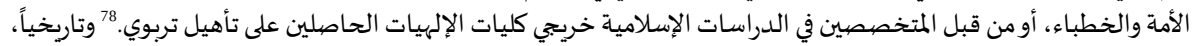

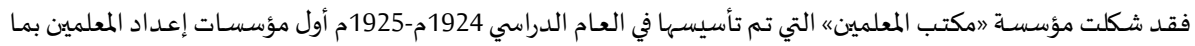

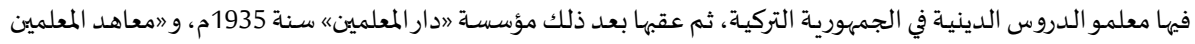

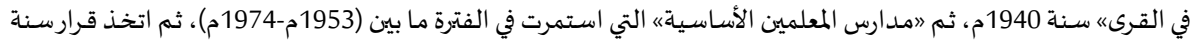

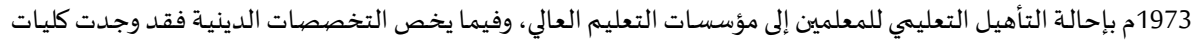

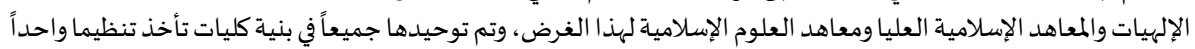

$$
\text { في مختلف الجامعات التركية تحت مسـى كلية الإلهيات. } 79
$$

وقد اتخذت هيئة التعليم العالي التركية عام 1998م قراراً بفتح أقسام "معلمي مجال الثقافة الدينية والمعارف الأخلاقيةها

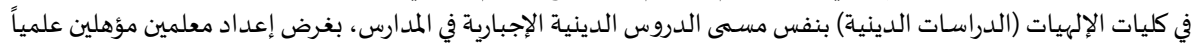

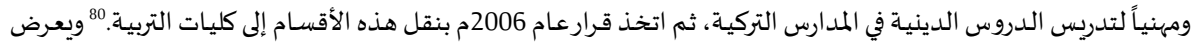

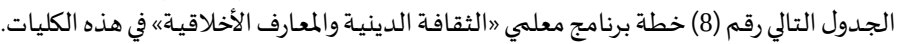

75 http://dogm.meb.gov.tr/meb_iys_dosyalar/2013_06/18101308_mamhatiportaokuluhaf. ders.iz..pdf.

76 http://dogm.meb.gov.tr/meb_iys_dosyalar/2013_07/10103624_19_06_2013_tarihli_ihl_9. siniflarhaftalik_ders_cizelgesi.pdf.

77 Recep Kaymakcan ve İbrahim Aşlamacı, Imam Hatip Lisleri Literatürü üzerini Bibliyografik bir Inceleme, s. 73.

7812 Yil Zorunlu Eğitim Sorular - Cevaplar, T. C. Millî Eğitim Bakanliği, Ankara, 2012, s: 28.

79 Recep Kaymakcan ve Diğerleri, Öğrencilerin Gözüyle İlk Öğretim Din Kültürü ve Ahlak Bilgisi Eğitimi Bölümleri Üzerinde bir Araştırma, Değerler Eğitim Dergisi, cilt: 9, No. 22, 103-138, 2011, S: 101.

80 Kaymakcan ve Diğerleri, Ögrrencilerin Gözüyle İlk Öğretim Din Kültürü ve Ahlak Bilgisi Eğitimi Bölümleri Üzerinde bir Araştırma, S: 103. 
جدول رقم (8) خطة برنامج معلمي »الثقافة الدينية والمعارف الأخلاقية《 في كليات التربية

\begin{tabular}{|c|c|c|c|c|c|c|c|c|c|c|}
\hline \multicolumn{2}{|c|}{ الثقافة العامة } & \multicolumn{2}{|c|}{ المقررات المسلكية } & \multicolumn{6}{|c|}{ مقررات التخصص } & \\
\hline & & & & \multicolumn{2}{|c|}{ الفلسفة والعلوم } & \multicolumn{2}{|c|}{ التارتخ الإسلامي } & \multicolumn{2}{|c|}{ أصول الدين الإسلامي } & \\
\hline | النسبة & الوحدات & النسبة & الوحدات & 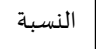 & الوحدات & النسبة & الوحدات & | النسبة & الوحدات & \\
\hline \multirow[t]{5}{*}{$\% 24.26$} & 41 & $\% 26.3$ & 44 & & 25 & & 11 & & 14 & \\
\hline & & & & & & & & $\% 3.55$ & 6 & العربية \\
\hline & & & & & & & & $\% 3.55$ & 6 & والتلاوة \\
\hline & & & & $\% 14.79$ & 25 & $\% 6.50$ & 11 & $\% 18.25$ & 26 & المجموع \\
\hline & & $\% 4.73$ & 8 & & & & & & & خاصة فاليب \\
\hline \multicolumn{2}{|c|}{$(\% 1.18) 2$} & & & \multicolumn{6}{|c|}{$(7.10 \%) 12$} & مواد حرة \\
\hline \multicolumn{2}{|c|}{ (\%.25) 43} & \multicolumn{2}{|c|}{ (\% 31) 52} & \multicolumn{6}{|c|}{ (\% 44) 74} & المجموع \\
\hline
\end{tabular}

Halit Ev, Türkiye'de Öğretmen Yetiştirme Sistemi ve Din Öğretimi Alanına Öğretmen Yetiştirme, DEÜ1FD, XXXIII/2011, ss. 9-50, s. 38-39.

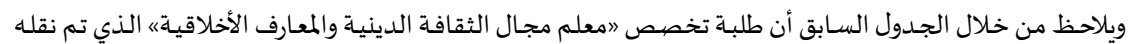

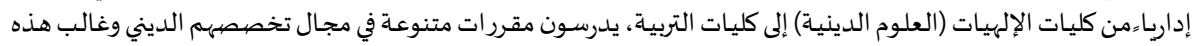

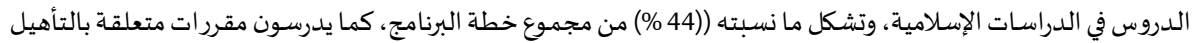
التربوي تشكل ما نسبته (31 \%) من مجموع دروس البرنامج، وتشكل مجموعة المقررات المتعلقة بالمعارف العامة ما ما نسبتها (25. \%) من مجمـوع دروس البرنامج.

الخاتمة

يعتبر ملف التعليم الديني أحد أهم الملفات التي طالها التغيرنتيجة التحولات التي شهدتها الدولة التركية، ويعتبر عام 2012م عاماً

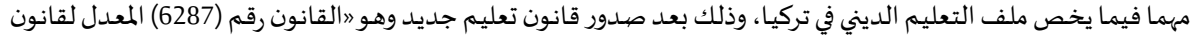

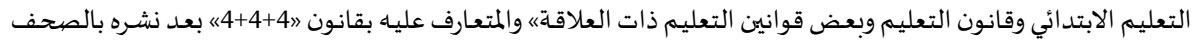

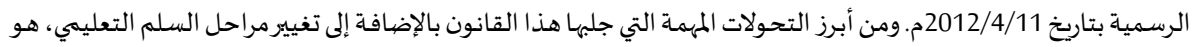

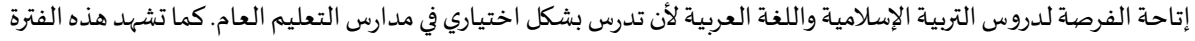

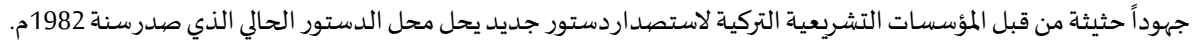

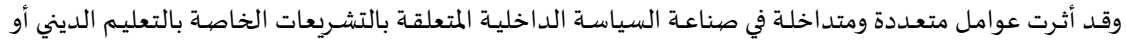

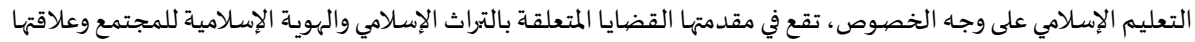

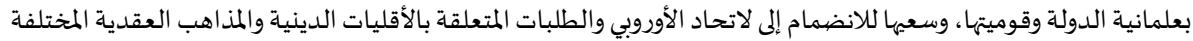




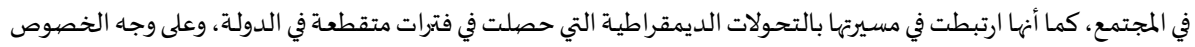

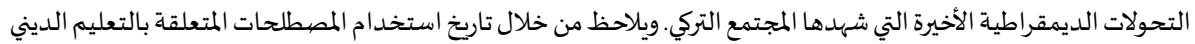

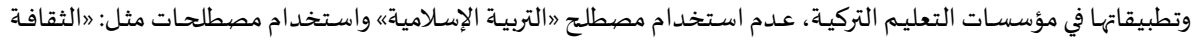

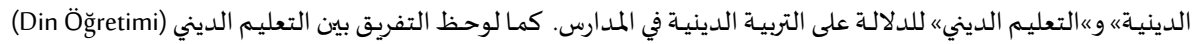

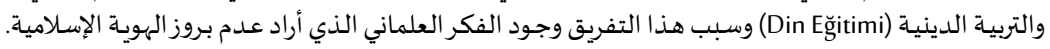

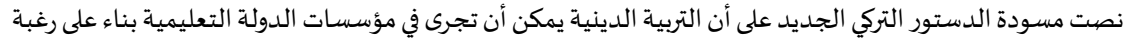

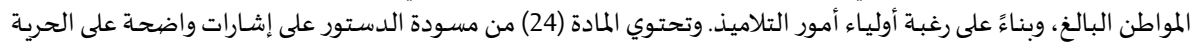

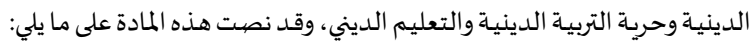

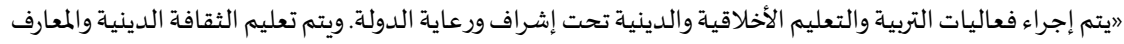

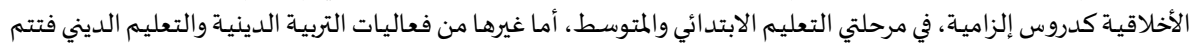

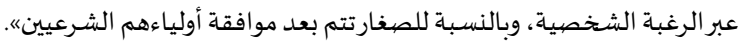

ويلاحظ أن هذه المادة تتضمن العناصر الأساسية التالية:

4. - أن يكون التعليم الديني داخل مراقبة وتنظيم الدولة.

5. أن يكون درس »الثقافة الدينية والمعارف الأخلاقية)《 مقرراً إلزاميا في المرحلتين الابتدائية والمتوسطة.

6. أن تكون دروس التربيـة والتعليم الديني الأخرى -خـارج دروس 》الثقافـة الدينيـة والمعارف الأخلاقيـة《-

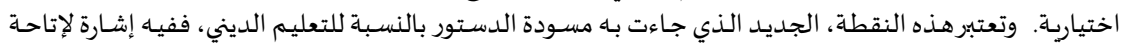

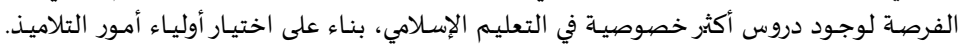

بدأ العمل بتطبيق »القانون رقم (6287) المعدل لقانون التعليم الابتدائي وقانون التعليم وبعض قوانين التعليم ذات

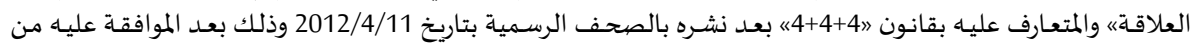

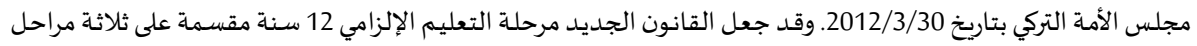

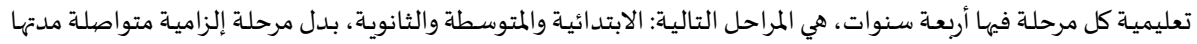

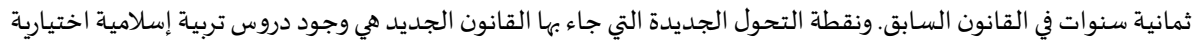

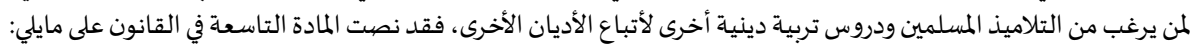

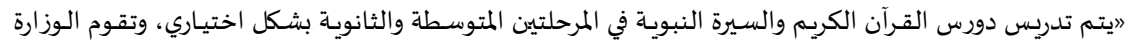

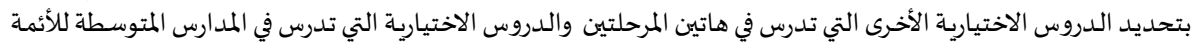

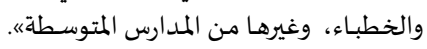

وبعد صيدور هـذا القانون تم تنظيم السـلم التعليمي ليشـمل مراحل ثلاثة هي الابتدائية والمتوسطة والثانويـة، وعندهـا

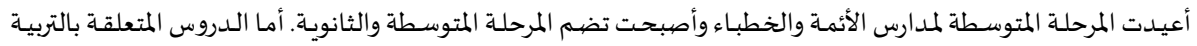

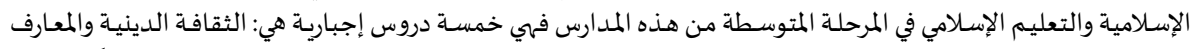

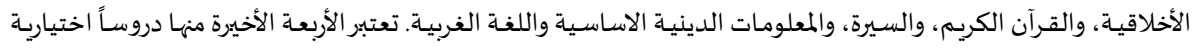

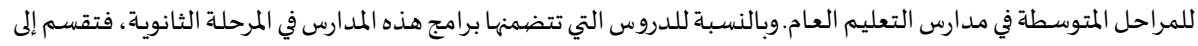

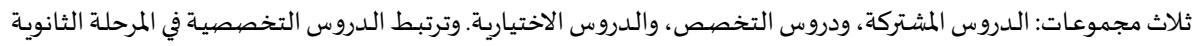

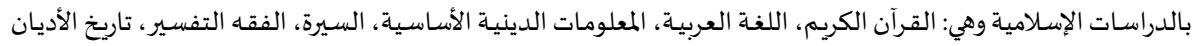

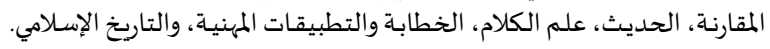

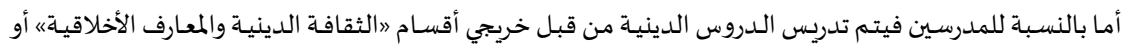

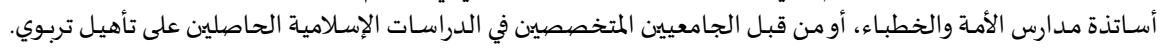




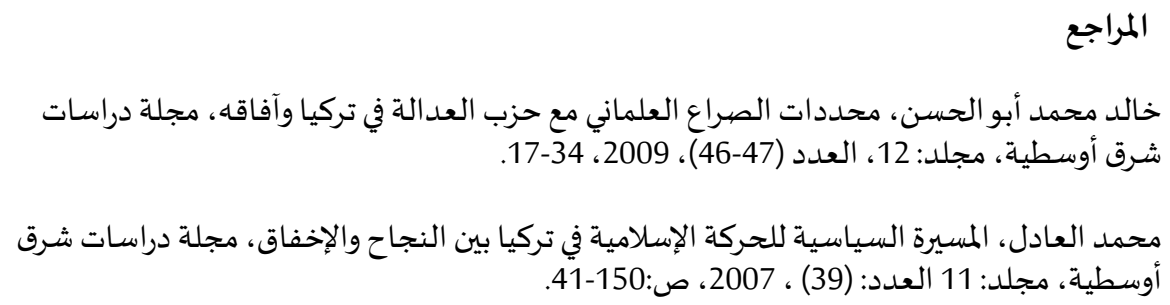

\section{Kaynakça}

2012 - 2013 Eğitim- Öğretim Yılı 4+4+4 Zorunlu Eğitim Yasasıyla Başlıyor, Eğitim ve Bilim İş Görenleri Sendikası, Ağustos 2012.

Karakas, Cemal "Turkey: Islam and Laicism Between the Interests of State, Peace Research Institute Frankfurt (PRIF) 2007, p. 27

Demirler, Derya Değişen Türkiye'de Din Toplum Ve Siyaset, Tesev Yayınları, İstanbul, 2006.

Mahçupyan, Etyen ve Diğerleri, Yeni Anayasa Sürecini İzleme Raporu: Nasıl Bir Anayasaya Doğru Gidiyoruz, Tesev Demokratikleşme Programi, 2013.

Ayhan, Halis Türkiye'de Din Eğitimi, İstanbul: M.Ü.İ.F Vakfı Nu.173, 1999.

Ev, Halit Türkiye'de Öğretmen Yetiştirme Sistemi ve Din Öğretimi Alanına Öğretmen Yetiştirme, DEÜ1FD, XXXIII/2011, ss. 9-50.

http:/ / dogm.meb.gov.tr/meb_iys_dosyalar/2013_06/18101308_mamhatiportaokuluhaf.ders. iz..pdf. http://dogm.meb.gov.tr/meb_iys_dosyalar/2013_07/10103624_19_06_2013_ tarihli_ihl_9.siniflarhaftalik_ders_cizelgesi.pdf.

http:/ / www.resmigazete.gov.tr/eskiler/2012/04/20120411-8.htm.

http: / / www.sabah.com.tr/Gundem/2013/09/30/basostusu-yasagi-kalkiyor.

Kurt, İhsan Türk Atasözlerine Psikolojik Bir Yaklaşım, Ankara: Kültür Bakanlığı, 1991 .

İlköğretim ve Eğitim Kanunu İle Bazı Kanunlarda Değişiklik Yapılmasına Dair Kanun Teklifi Hakkında Bazı Değerlendirme Ve Öneriler (4+4+4 Eğitim Sistemi), Ensar Vakfi, İstanbul, 2012.

Başkurt, İrfan "Federal Almanya'da Din Eğitimi", Marmara Üniversitesi Sosyal Bilimler Enstitüsü (Yayınlanmamış Yüksek Lisans Tezi), 1994.

Bozan, İrfan Devlet ile Toplum arasında bir Okul olarak Imam Hatip liseleri bir Kurum olarak Diyanet İşleri Başkanlığı, Tesev Yayınları, İstanbul, 2007.

İstatistiklerle Türkiye 2012, Türkiye İstatistik Kurumu, Türkiye İstatistik Kurumu Matbaası, 2013.

İsteğe Bağ̆l Din Eğitimi Raporu, Ensar Vakfi, İstanbul, 2012.

İsmailefendioğlu, M. Besim "Hollanda'da Din Eğitimi", Marmara Üniversitesi Sosyal Bilimler Enstitüsü (Yayınlanmamış Doktora Tezi), 1997.

Toptaş, Mahmut Kur'ân-ı Kerim Şifa Tefsiri, 1.baskı, İstanbul: Cantaş Yayınları, 1997.

Medine Sevim, Türkiye'de Cumhuriyet Dönemi Din Eğitimi ve Öğretimi Kronolojisi, Dem dergi, say1:2, 2011, 64-71

Bahçekapıll, Mehmet ve diğerleri, Türkiye'de Din Eğitiminin Dönüşümü (1997-2012) Raporu, İLKE İlim Kültür Eğitim Derneği, İstanbul 2012, s: 192.

Aydın, Mehmet Zeki, “Tunus'ta İlk ve Orta Dereceli Okullardaki Din Öğretimi Programları”, CÜ İlâhiyat Fakültesi Dergisi, S.2,1998, s.263-284.

Aydın, Mehmet Zeki "Yeni Anayasa ve Din Dersi Tartışmaları", Düşünce Platformu Dergisi, Ankara 2008, y1l:3, sayı:30, ss.120-125

Thalgi, Mohammad "Ürdün'de Din Eğitimi”, Marmara Üniversitesi Sosyal Bilimler Enstitüsü (Yayınlanmamış Doktora Tezi), 2007. 
Poyraz, Tuğça ve Gülay Arıkan, "Avrupa-Türkiye Ilişkileri ve Avrupa Yayılmacıllı̆ından Sonra Değişen "Öteki" Tanımları, Hacettepe Üniversitesi Edebiyat Fakültesi Dergisi, 2004 / cilt: 21 / sayi: 2 / ss. 1-16

Kaymakcan, Recep ve Diğerleri, "Öğrencilerin Gözüyle İlk Öğretim Din Kültürü ve Ahlak Bilgisi Eğitimi Bölümleri Üzerinde bir Araştırma, Değerler Eğitim Dergisi", cilt: 9, No. 22, 103-138, 2011.

Kaymakcan, Recep ve diğerleri, Seçmeli Din Eğitimi Dersleri İnceleme ve Değerlendirme Raporu, Çınar Basım Yayın, İstanbul, 2013.

Kaymakcan, Recep AIHM Din Dersi Kararı Nasıl Anlaşılmall, DEM Dergi, Yıl 1 Sayı 2, 2007.

Kaymakcan, Recep Günümüz İngiltere'sinde Din Eğitimi, 1.baskı, İstanbul: Değerler Eğitim Merkezi, 2004.

Aydın, Senem and Ruşen Çakır, Political Islam in Turkey, Center for European Policy, 265 (2007): 1-12.

Uluslararası Azınlık Hakları Grubu 2007, Bir Eşitlik Arayışı: Türkiye'de Azınlıklar, United Kingdom, London, 2007.

Yeni Anayasa'da Dini Kurumlar Din Ĕ̆itimi Ve Öğretimi Raporu, Ensar Vakfi, İstanbul, 2012.

Yıldız, Süleyman, Kimlik Ve Ulusal Kimlik Kavramlarinin Toplumsal Niteliği, Millı̂ Folklor, 2007, Y11 19, Say: 74, s.9-16

Arslan, Zühtü, Başörtüsü, Ak Parti ve Laiklik: Anayasa Mahkemesinden İki Karar Bir Gerekçe, S E TA, Sayı: 2 Ocak, 2009, s. 3-25 